\title{
PENGARUH PEMBERIAN SUSU KEDELAI TERHADAP KADAR GLUKOSA DARAH PUASA PADA WANITA PREDIABETES
}

\author{
Evi Sinaga, Yekti Wirawanni* \\ Program Studi Ilmu Gizi Fakultas Kedokteran Universitas Diponegoro \\ Jl.Dr.Sutomo No.14, Semarang, Telp (024) 8453708, Email : gizifk@undip.ac.id
}

\begin{abstract}
Background : Prediabetic stage is characterized by fasting blood glucose (FBG) between 100 -125 mg/dl. Diabetic management is effective in prediabetic stage. Soy milk is one of foodstuff that was correlated to blood glucose decreasing. The purpose of this study was to prove effect of soy milk on FBG in prediabetic women.

Method : This research was quasi experiment study with pre test-post test design that included 30 women. The subjects were people in Tlogosari Kulon Semarang who taken by purposive sampling, were divided in 2 groups. The treatment group was given soy milk $280 \mathrm{ml}$ per day during 14 days and control group wasn't given soy milk. FBG was measured before and after intervention using spectrofotometric method. During intervention, both of groups recorded food intake using food record $14 \times 24$ hours and food recall $3 \times 24$ hours. Data was analyzed by Independent sample t-test, Mann Whitney test, Wilcoxon test, bivariate analysis and linear regression.

Result : FBG treatment group was significantly decreased $(p=0.001)$ by $26.31 \pm 11.38 \mathrm{mg} / \mathrm{dl}$ and FBG control group increased by $0.07 \pm 10.81 \mathrm{mg} / \mathrm{dl}$. Statistic analysis showed that there was significant difference FBG change between treatment group and control group. The correlation between physical activity, BMI change and fiber intake change in conjunction with FBG change was 0.561 .

Conclusion : There is significant fasting blood glucose decreasing after given soy milk 280 ml per day during 14 days. Physical activity, BMI change and fiber intake change contributed to FBG decreasing.
\end{abstract}

Key word : soy milk; fasting blood glucose; prediabetic women

\begin{abstract}
ABSTRAK
Latar Belakang : Prediabetes ditandai dengan kadar glukosa darah puasa (GDP) antara 100 - 125 mg/dl. Manajemen diabetes efektif dilakukan pada tahap prediabetes. Susu kedelai merupakan produk olahan kedelai yang dihubungkan dengan penurunan kadar glukosa darah. Penelitian ini bertujuan membuktikan pengaruh pemberian susu kedelai terhadap kadar GDP pada wanita prediabetes.

Metode : Jenis penelitian ini quasi eksperiment dengan pre test-post test design. Subjek penelitian adalah warga Kelurahan Tlogosari Kulon Semarang, diambil secara purposive sampling sebanyak 30 orang, dibagi secara acak dalam 2 kelompok. Kelompok perlakuan diberi susu kedelai sebanyak $280 \mathrm{ml} / \mathrm{hari}$ selama 14 hari, sedangkan kelompok kontrol tidak. Kadar GDP diukur sebelum dan setelah intervensi menggunakan metode spektrofotometri. Asupan makan kedua kelompok selama intervensi diperoleh dengan metode food record $14 \times 24$ jam dan food recall $3 \times 24$ jam. Analisis statistik menggunakan Independent sample t-test, Mann-Whitney test, Wilcoxon test, analisis bivariat dan regresi linear.

Hasil : Kelompok perlakuan mengalami penurunan kadar GDP yang bermakna (p=0.001) sebesar 26.31 \pm 11.38 $\mathrm{mg} / \mathrm{dl}$ sedangkan kelompok kontrol mengalami peningkatan sebesar $0.07 \pm 10.81 \mathrm{mg} / \mathrm{dl}$. Uji statistik menunjukkan terdapat perbedaan perubahan kadar GDP yang bermakna antara kelompok perlakuan dan kontrol. Terdapat korelasi antara aktifitas fisik, perubahan IMT dan perubahan asupan serat secara bersamaan dengan perubahan GDP sebesar 0.561 .
\end{abstract}

Simpulan : Terdapat penurunan kadar GDP yang bermakna setelah pemberian $280 \mathrm{ml}$ susu kedelai selama 14 hari. Variabel aktifitas fisik, perubahan IMT dan perubahan asupan serat ikut berkontribusi terhadap penurunan GDP.

Kata kunci : Susu kedelai; kadar glukosa darah puasa; wanita prediabetes

\section{PENDAHULUAN}

Diabetes mellitus (DM) merupakan sekumpulan gejala yang timbul pada seseorang, ditandai dengan kadar glukosa darah melebihi nilai normal dan gangguan metabolisme insulin. Penderita DM tidak mampu mensekresi insulin dalam jumlah cukup, menggunakan insulin secara efektif ataupun keduanya. DM jangka panjang dapat menimbulkan rangkaian gangguan metabolik yang menyebabkan kelainan patologis makrovaskular dan mikrovaskular. ${ }^{1}$

Jumlah penderita DM meningkat dengan cepat di seluruh dunia dan penyakit ini sudah merupakan suatu penyakit epidemi global. Laporan

${ }^{*}$ Penulis Penanggungjawab 
dari World Health Organization (WHO) mengenai studi populasi DM di berbagai negara, Indonesia menempati urutan ke-4 pada tahun 2000 dengan jumlah penderita DM 8,4 juta jiwa setelah India (31,7 juta), Cina (20,8 juta), dan Amerika Serikat $\left(17,7\right.$ juta). ${ }^{2,3}$ Secara epidemiologi, WHO memperkirakan pada tahun 2030 jumlah penderita DM di Indonesia mencapai 21,3 juta jiwa. ${ }^{4}$ Penelitian yang dilakukan oleh Soewondo dan Pramono tahun 2011 menunjukkan prevalensi prediabetes di Indonesia sebesar 10\%. ${ }^{5}$ Tahun 2010 DM menduduki urutan kedua sebagai penyakit tidak menular terbanyak di Kota Semarang dengan prevalensi $20,5 \%$ setelah penyakit jantung dan pembuluh darah. $^{6}$

Besarnya insidensi, prevalensi, dan komplikasi DM menggambarkan betapa pentingnya pencegahan dan penatalaksanaan dini penyakit tersebut. Manajemen DM sangat efektif dilakukan pada tahap awal sebelum timbul gejala atau prediabetes. ${ }^{7}$ Prediabetes ditandai dengan kadar glukosa darah puasa antara 100-125 mg/dl. Wanita memiliki risiko yang lebih tinggi mengalami prediabetes dibandingkan pria. Prediabetes merupakan salah satu faktor risiko terjadinya gangguan kardiovaskular. Kondisi prediabetes dapat diperbaiki dengan merubah gaya hidup sedentary, menurunkan berat badan, mengatur diet, dan melakukan olahraga secara teratur. ${ }^{8,9}$

Salah satu bahan makanan yang dihubungkan dengan perbaikan kondisi prediabetes melalui penurunan kadar glukosa darah adalah kedelai. Kebiasaan konsumsi kacang-kacangan terutama kedelai memiliki risiko protektif terhadap DM Tipe $2 .{ }^{10}$ Kandungan protein, isoflavon, serat, lesitin serta rendahnya indeks glikemik kedelai merupakan komponen yang memberikan efek hipoglikemik. ${ }^{7,11,12}$ Kandungan tersebut, terutama protein juga terdapat dalam produk olahan kedelai; antara lain tempe, tahu, soygurt, dan susu kedelai. ${ }^{12}$

Penelitian menunjukkan konsumsi kedelai dan protein kedelai serta isoflavon dapat menurunkan resistensi insulin dan memperbaiki kontrol glukosa darah penderita DM. ${ }^{13}$ Penelitian lain memberikan hasil yang berbeda, pemberian 15 $\mathrm{g}$ protein kedelai dan $100 \mathrm{mg}$ isoflavon pada 180 wanita postmenopause Hongkong-Cina prediabetes tidak memperbaiki sensitifitas insulin dan kontrol glukosa darah. ${ }^{7}$ Kedua penelitian ini menunjukkan hasil yang tidak konsisten mengenai peran kedelai dalam memperbaiki resistensi insulin dan kontrol glukosa darah. Pemberian $5 \mathrm{ml}$ susu kedelai rumah tangga dan susu kedelai bubuk pada tikus DM selama 14 hari menurunkan glukosa darah puasa secara bermakna. ${ }^{14}$ Penelitian pada manusia yaitu pemberian susu kedelai dalam diet pasien DM di Rumah Sakit dr. Saiful Anwar Malang juga menunjukkan penurunan bermakna glukosa darah puasa dan glukosa darah 2 jam post prandial. ${ }^{15}$

Data yang diperoleh dari Dinas Kesehatan Kota Semarang jumlah kunjungan pasien DM Tipe 2 di Puskesmas Tlogosari Kulon pada tahun 2011 sebanyak 2957 kasus, dimana merupakan puskesmas dengan jumlah kunjungan pasien DM terbanyak. Penelitian mengenai efek hipoglikemik glukosa darah oleh susu kedelai pada penderita DM sudah pernah dilakukan, namun penelitian pemberian susu kedelai pada penderita prediabetes belum pernah dilakukan. Hasil penelitian mengenai peran kedelai dalam memperbaiki sensitiftas insulin dan kontrol glukosa darah belum memberikan hasil yang konsisten. Berdasarkan latar belakang tersebut, peneliti tertarik untuk meneliti pengaruh pemberian susu kedelai terhadap kadar glukosa darah puasa pada wanita prediabetes.

\section{METODE}

Tujuan penelitian ini adalah membuktikan pengaruh pemberian susu kedelai terhadap kadar glukosa darah puasa pada wanita prediabetes. Penelitian dilakukan di wilayah kerja Puskesmas Tlogosari Kulon Semarang pada bulan Mei - Juni 2012. Jenis penelitian adalah quasi eksperimen dengan rancangan pre test-post test design. Subjek penelitian adalah warga Kelurahan Tlogosari Kulon Semarang yang diambil secara purposive sampling. Besar subjek dalam penelitian adalah 30 orang. Kriteria inklusi meliputi wanita berusia 4055 tahun, IMT $23-29.9 \mathrm{~kg} / \mathrm{m}^{2}$ yaitu kategori overweight dan obesitas I menurut International Obesity Task Force (IOTF) dan $\mathrm{WHO}^{16}$, kadar glukosa darah puasa (GDP) $100-125 \mathrm{mg} / \mathrm{dl}$, tidak mengkonsumsi obat-obatan yang mengendalikan kadar glukosa darah, dalam keadaan sadar dan dapat diajak komunikasi, dan tidak dalam keadaan sakit atau dalam perawatan dokter. Kriteria eksklusi adalah mengundurkan diri sebagai subjek penelitian, sakit, dan tidak taat pada prosedur penelitian.

Prosedur pertama dalam penelitian ini adalah memberikan penjelasan tentang maksud penelitian, metode penelitian, risiko dan ketidaknyamanan yang akan dialami serta keuntungan yang diperoleh subjek penelitian. Setelah itu peneliti menawarkan kesediaan menjadi subjek penelitian. Subjek yang telah bersedia diminta untuk menandatangani 
informed consent. Selanjutnya, dilakukan pengukuran berat badan (BB) dan tinggi badan (TB) untuk mengetahui IMT, wawancara data umum subjek serta proses penapisan kadar glukosa darah puasa.

Subjek yang memenuhi kriteria inklusi dibagi ke dalam 2 kelompok secara acak. Kelompok pertama diberikan susu kedelai sebanyak $280 \mathrm{ml}$ selama 14 hari, sedangkan kelompok kedua tidak diberikan susu kedelai. Dosis pemberian susu kedelai berdasarkan dosis yang diberikan pada tikus dalam penelitian sebelumnya yang mana dapat menurunkan kadar glukosa darah tikus secara bermakna. Setelah dikonversi, maka diperoleh dosis $280 \mathrm{mg} /$ hari. $^{10}$ Setelah pemberian susu kedelai selama 14 hari, hari ke-15 dilakukan pengambilan darah pada kelompok perlakuan dan kontrol untuk mengetahui kadar glukosa darah puasa. Selama penelitian, peneliti mencatat dan memantau efek pemberian susu kedelai yang dirasakan oleh subjek penelitian. Kepatuhan dan waktu mengkonsumsi susu kedelai dipantau dengan menggunakan formulir chek list yang diisi oleh peneliti dengan menanyakan langsung kepada subjek penelitian.

Data yang dikumpulkan melalui wawancara adalah data umum subjek, data asupan makan dan aktifitas fisik. Data yang dikumpulkan melalui pengukuran antropometri adalah data berat badan yang diperoleh melalui penimbangan dengan timbangan digital dan data tinggi badan yang diperoleh melalui pengukuran dengan microtoise. Sedangkan, pengukuran laboratorium yaitu kadar glukosa darah puasa dilakukan oleh petugas laboratorium " $\mathrm{T}$ " menggunakan metode spektrofotometri.

Variabel bebas pada penelitian ini adalah pemberian susu kedelai cair tawar olahan rumah tangga merupakan ekstra kedelai varietas Americana, usia panen 93-97 hari, diperoleh melalui proses penyortiran, pencucian, perendaman 5-8 jam, penirisan, penggilingan, penyaringan, perebusan ekstrak dan pengemasan. Pemberian susu kedelai disertai pemberian 1 sachet gula jagung " $\mathrm{T}$ " yang mengandung pemanis sorbitol $1.97 \mathrm{mg}$, pemanis sukralose $9.8 \mathrm{mg}$, pemanis asesulfam $8 \mathrm{mg}$, bubuk jagung dan kromium pikolinat. Susu kedelai diberikan sebanyak $280 \mathrm{ml}$ selama 14 hari sebagai snack pagi atau selang waktu antara makan pagi dan makan siang. Variabel terikat adalah kadar glukosa darah puasa yang diukur setelah subjek penelitian berpuasa selama 10 jam, diambil pada pembuluh vena mediana cubiti di lengan, dengan satuan $\mathrm{mg} / \mathrm{dl}$, yang pengukurannya dilakukan oleh petugas laboratorium "T". Sedangkan variabel perancu adalah asupan energi, karbohidrat, protein, lemak dan serat selama penelitian yang diperoleh dengan metode food record selama $14 \times 24$ jam dan food recall $3 \times 24$ jam dan diolah menggunakan nutrisurvey.

Data yang diperoleh dianalisis secara statistik. Gambaran karakteristik subjek dianalisis dengan analisis deskriptif. Uji normalitas data menggunakan uji Shapiro Wilk. Uji statistik lain yang digunakan yaitu uji Wilcoxon, uji MannWhitney, uji Independent sample t test, uji korelasi bivariat dan uji regresi linear.

\section{HASIL PENELITIAN}

Skrining dilakukan pada 182 wanita yang bersedia diperiksa kadar glukosa darah puasanya dan sebanyak 30 orang dari jumlah tersebut memenuhi kriteria inklusi menjadi subjek penelitian. Namun, sebanyak 2 orang subjek pada kelompok perlakuan drop out karena tidak mematuhi prosedur penelitian. Jumlah subjek yang mengikuti penelitian hingga akhir adalah 28 orang dan memenuhi besar sampel minimal yaitu 28 orang.

Tabel 1. Karakteristik subjek penelitian

\begin{tabular}{lcccc}
\hline \multirow{2}{*}{ Karakteristik Subjek } & \multicolumn{2}{c}{ Perlakuan $(\mathrm{n}=13)$} & \multicolumn{2}{c}{ Kontrol $(\mathrm{n}=15)$} \\
\cline { 2 - 5 } & $\mathrm{n}$ & $\%$ & $\mathrm{n}$ & $\%$ \\
\hline Kelompok Usia & 6 & 21.4 & 2 & 7.1 \\
40 - 47 tahun & 7 & 25.0 & 13 & 46.4 \\
$48-55$ tahun & 0 & 0.0 & 1 & 3.6 \\
\hline Tingkat Pendidikan & 3 & 10.7 & 1 & 3.6 \\
Tidak sekolah & 4 & 14.3 & 2 & 7.1 \\
Tamat SD & 6 & 21.4 & 6 & 21.4 \\
Tamat SMP & & & & \\
Tamat SMA &
\end{tabular}




\begin{tabular}{|c|c|c|c|c|}
\hline Tamat Perguruan Tinggi & 0 & 0.0 & 5 & 17.9 \\
\hline \multicolumn{5}{|l|}{$\mathrm{IMT}^{16}$} \\
\hline Overweight $\left(23-24,9 \mathrm{~kg} / \mathrm{m}^{2}\right)$ & 3 & 10.7 & 3 & 10.7 \\
\hline Obesitas I $\left(25-29,9 \mathrm{~kg} / \mathrm{m}^{2}\right)$ & 10 & 35.7 & 12 & 42.9 \\
\hline \multicolumn{5}{|l|}{ Aktifitas Fisik $^{17}$} \\
\hline Ringan & 2 & 7.1 & 3 & 10.7 \\
\hline Sedang & 11 & 39.3 & 12 & 42.9 \\
\hline
\end{tabular}

Tabel 1 menunjukkan subjek pada kelompok kontrol berusia lebih tua dari kelompok perlakuan. Kelompok kontrol lebih terdidik dibanding kelompok perlakuan. Indeks massa tubuh (IMT) subjek yang tergolong obesitas I lebih banyak ditemukan pada kelompok kontrol (42.9\%). Tingkat aktifitas sedang lebih banyak pada subjek kelompok kontrol (42.9\%) daripada kelompok perlakuan.

\section{Karakteristik Awal Subjek Penelitian}

Karakteristik usia, IMT dan aktifitas fisik mempengaruhi kadar glukosa darah kelompok perlakuan dan kontrol.

Tabel 2. Karakteristik awal subjek penelitian

\begin{tabular}{lccc}
\hline \multirow{2}{*}{ Variabel } & Perlakuan $(\mathrm{n}=13)$ & Kontrol $(\mathrm{n}=15)$ & \multirow{2}{*}{$P^{*}$} \\
\cline { 2 - 3 } & Rerata \pm SB & Rerata \pm SB & \\
\hline Usia & $48.15 \pm 5.40$ & $51.67 \pm 3.72$ & $0.053^{*}$ \\
IMT & $26.10 \pm 1.93$ & $27.43 \pm 2.41$ & $0.102^{*}$ \\
Aktifitas fisik & $2381.4 \pm 130.25$ & $2372.9 \pm 173.70$ & $0.886^{*}$ \\
& & & $*$ \\
\hline
\end{tabular}

*uji Mann-Whitney **uji independent sample t-test

Tabel 2 menunjukkan secara statistik tidak terdapat perbedaan rerata usia, IMT dan aktifitas fisik yang bermakna $(p>0.05)$ antara kelompok perlakuan dan kontrol. Hal ini menggambarkan bahwa keadaan awal subjek penelitian adalah homogen.

\section{Asupan Makan Sebelum Intervensi}

Asupan makan merupakan faktor yang mempengaruhi kadar glukosa darah. Asupan tersebut meliputi asupan energi, protein, lemak, karbohidrat dan serat.

Tabel 3. Asupan makan sebelum intervensi

\begin{tabular}{lccc}
\hline \multirow{2}{*}{ Variabel } & Perlakuan $(\mathrm{n}=13)$ & Kontrol $(\mathrm{n}=15)$ & \multirow{2}{*}{$p^{*}$} \\
\cline { 2 - 3 } & Rerata $\pm \mathrm{SB}$ & Rerata $\pm \mathrm{SB}$ & \\
\hline Asupan energy & $1500.2 \pm 260.97$ & $1689.6 \pm 221.92$ & $0.048^{*}$ \\
& $40.44 \pm 7.48$ & $42.5 \pm 9.19$ & 0.525 \\
Asupan protein & $53.48 \pm 8.29$ & $60.57 \pm 9.56$ & $0.047^{*}$ \\
Asupan lemak & $213.78 \pm 44.54$ & $243.15 \pm 32.31$ & 0.054 \\
& $12.05 \pm 1.87$ & $12.67 \pm 1.99$ & 0.400 \\
Asupan karbohidrat & &
\end{tabular}

Tabel 3 menunjukkan terdapat perbedaan yang bermakna $(p<0.05)$ antara asupan energi dan lemak sebelum intervensi kelompok perlakuan dan kelompok kontrol. Asupan energi, protein, lemak, karbohidrat dan serat sebelum intervensi kelompok kontrol lebih tinggi dari pada kelompok perlakuan.

\section{Asupan Makan selama Intervensi}

Asupan makan selama intervensi pada kedua kelompok digunakan untuk melihat perubahan asupan makan subjek. 
Tabel 4. Asupan makan selama intervensi

\begin{tabular}{lccc}
\hline \multirow{1}{*}{\multicolumn{1}{c}{ Variabel }} & Perlakuan $(\mathrm{n}=13)$ & Kontrol $(\mathrm{n}=15)$ & \multirow{2}{*}{$p^{*}$} \\
\cline { 2 - 3 } & Rerata $\pm \mathrm{SB}$ & Rerata \pm SB & \\
\hline Asupan energy & $1489.9 \pm 271.64$ & $1656.8 \pm 224.50$ & 0.087 \\
Asupan protein & $42.98 \pm 106.04$ & $43.24 \pm 7.25$ & 0.939 \\
Asupan lemak & $53.11 \pm 9.86$ & $59.25 \pm 11.62$ & 0.147 \\
Asupan karbohidrat & $211.72 \pm 50.36$ & $237.78 \pm 34.51$ & 0.118 \\
Asupan serat & $12.18 \pm 2.26$ & $12.61 \pm 2.52$ & 0.636 \\
\hline
\end{tabular}

*uji independent sample t-test

Tabel 4 menunjukkan tidak terdapat perbedaan asupan energi, protein, lemak, karbohidrat dan serat yang bermakna selama intervensi antara kelompok perlakuan dengan kelompok kontrol $(p>0.05)$. Namun, asupan energi, protein, lemak, karbohidrat dan serat selama intervensi pada kelompok kontrol lebih tinggi dari pada kelompok perlakuan.

Perubahan Asupan Makan

Perubahan asupan makan selama intervensi dapat menjadi salah satu faktor yang berperan dalam perubahan kadar glukosa darah.

Tabel 5. Perubahan asupan makan

\begin{tabular}{lccc}
\hline \multicolumn{1}{c}{ Variabel } & Perlakuan $(\mathrm{n}=13)$ & Kontrol $(\mathrm{n}=15)$ & \multirow{2}{*}{$p^{*}$} \\
\cline { 2 - 3 } & Rerata \pm SD & Rerata \pm SD & 0.765 \\
\hline$\Delta$ Asupan energy & $-10.31 \pm 166.62$ & $-32.80 \pm 218.83$ & 0.458 \\
$\Delta$ Asupan protein & $2.54 \pm 6.07$ & $0.74 \pm 6.50$ & 0.450 \\
$\Delta$ Asupan lemak & $-0.37 \pm 11.20$ & $-1.33 \pm 7.53$ & 0.790 \\
$\Delta$ Asupan karbohidrat & $-2.07 \pm 32.98$ & $-5.37 \pm 45.07$ & 0.829 \\
$\Delta$ Asupan serat & $0.13 \pm 1.99$ & $-0.06 \pm 2.93$ & $0.818^{*}$ \\
& & & $*$ \\
\hline
\end{tabular}

*uji independent sampel t-test **uji Mann-Whitney

Tabel 5 menunjukkan tidak terdapat perbedaan yang bermakna $(p>0.05)$ antara perubahan asupan energi, protein, lemak, karbohidrat dan serat kelompok perlakuan dan kontrol. Kelompok perlakuan mengalami penurunan asupan energi, lemak, dan karbohidrat. Sedangkan, kelompok kontrol mengalami penurunan asupan energi, lemak, karbohidrat dan serat.

Daya Terima Susu Kedelai pada Kelompok Perlakuan
Rerata asupan susu kedelai pada kelompok perlakuan adalah $279,56 \mathrm{ml}$ per hari $(99,84 \%)$. Hal ini disebabkan sebanyak 1 orang subjek tidak menghabiskan susu kedelai dalam sehari dengan alasan kekenyangan, sehingga menyisakan $200 \mathrm{ml}$ susu kedelai.

Perbedaan Kadar Glukosa Darah Puasa (GDP) sebelum dan setelah Intervensi

Glukosa darah puasa seluruh subjek penelitian sebelum intervensi tergolong prediabetes (100-125 mg/dl).

Tabel 6. Perbedaan kadar GDP sebelum dan setelah intervensi

\begin{tabular}{|c|c|c|c|c|c|}
\hline \multirow[b]{2}{*}{ Variabel } & \multicolumn{2}{|c|}{ GDP } & \multirow[b]{2}{*}{$p^{* *}$} & \multirow[b]{2}{*}{$\begin{array}{l}\Delta \mathrm{GDP} \\
(\mathrm{mg} / \mathrm{dl})\end{array}$} & \multirow[b]{2}{*}{$P^{* * *}$} \\
\hline & $\begin{array}{l}\text { sebelum } \\
\text { intervensi } \\
(\mathrm{mg} / \mathrm{dl})\end{array}$ & $\begin{array}{l}\text { setelah } \\
\text { intervensi } \\
(\mathrm{mg} / \mathrm{dl})\end{array}$ & & & \\
\hline $\begin{array}{l}\text { Perlakuan } \\
(\mathrm{n}=13)\end{array}$ & & & & & \\
\hline Rerata \pm SB & $110.62 \pm 7.10$ & $84.31 \pm 8.45$ & $\begin{array}{l}0.001 \\
*\end{array}$ & $26.31 \pm 11.38$ & $\begin{array}{l}0.000 \\
*\end{array}$ \\
\hline Kontrol $(n=15)$ & & & & & \\
\hline Rerata \pm SB & $107.53 \pm 8.99$ & $107.60 \pm 8.45$ & 0.916 & $-0.07 \pm 10.81$ & \\
\hline
\end{tabular}


Kelompok perlakuan mengalami penurunan kadar GDP secara bermakna $(p=0,001)$ setelah pemberian susu kedelai selama 14 hari yaitu sebesar $26.31 \pm 11.38 \mathrm{mg} / \mathrm{dl}$. Terdapat perbedaan perubahan kadar GDP yang bermakna $(p=0,000)$ antara kelompok perlakuan dan kelompok kontrol.

\begin{abstract}
Hubungan dan Pengaruh variable perancu terhadap perubahan GDP pada kelompok perlakuan

GDP dapat dipengaruhi oleh beberapa variabel perancu, oleh karena itu dilakukan uji korelasi dan regresi untuk mengetahui variabel perancu mana yang ikut berkontribusi dalam penurunan GDP pada kelompok perlakuan.
\end{abstract}

Tabel 7. Hubungan dan pengaruh variabel perancu terhadap perubahan GDP pada kelompok perlakuan

\begin{tabular}{lccccc}
\hline \multicolumn{1}{c}{ Variabel } & $\begin{array}{c}\text { koefisien } \\
\text { korelasi }\end{array}$ & $\begin{array}{c}\boldsymbol{p}^{* *} \\
\mathbf{u j i} \\
\text { korelasi }\end{array}$ & $\mathbf{r}$ & $\begin{array}{c}\boldsymbol{p} \\
\mathbf{u j i} \\
\text { regresi }\end{array}$ & $\begin{array}{c}\mathbf{R} \\
\text { square }\end{array}$ \\
\hline Aktivitas fisik & 0.030 & $0.200^{*}$ & 0.769 & $0.029^{*}$ & \\
$\Delta$ IMT & 0.381 & $0.224^{*}$ & 0.764 & $0.031^{*}$ & 0.561 \\
$\Delta$ asupan serat*** & 0.669 & $0.012 *$ & 0.567 & $0.021^{*}$ & \\
$\Delta$ asupan energi & 0.128 & 0.676 & - & - & - \\
$\Delta$ asupan protein & -0.034 & 0.912 & - & - & - \\
$\Delta$ asupan lemak & -0.333 & 0.915 & - & - & - \\
$\Delta$ asupan karbohidrat & 0.144 & 0.639 & - & - & - \\
Usia & 0.239 & 0.431 & - & - & - \\
*signifikan **uji korelasi Pearson ***uji korelasi Spearman's & &
\end{tabular}

Hasil uji korelasi menunjukkan aktifitas fisik, perubahan IMT dan perubahan asupan serat berkorelasi positif secara bermakna $(p<0,05)$ dengan perubahan GDP. Aktifitas fisik maupun perubahan IMT memiliki kekuatan korelasi yang kuat dengan perubahan GDP, sedangkan perubahan asupan serat memiliki kekuatan korelasi yang sedang dengan perubahan GDP. Korelasi antara aktifitas fisik, perubahan IMT dan perubahan asupan serat secara bersamaan dengan perubahan GDP adalah 0.561atau $56.10 \%$ perubahan GDP dapat dijelaskan oleh variabel aktifitas fisik, perubahan IMT dan perubahan asupan serat.

\section{PEMBAHASAN}

Seluruh subjek dalam penelitian ini berjenis kelamin wanita. Penderita prediabtes di Indonesia didominasi oleh wanita. ${ }^{5}$ Risiko gangguan toleransi glukosa lebih tinggi pada wanita dibanding pria karena komposisi lemak tubuh yang tinggi menyebabkan wanita cenderung lebih mudah gemuk. Disamping itu, wanita juga memiliki aktifitas fisik yang lebih rendah dibanding pria. ${ }^{18}$

Rerata usia subjek pada kelompok kontrol (51.67 \pm 3.72) lebih tinggi dari kelompok perlakuan $(48.15 \pm 5.40)$, sehingga dapat dikatakan subjek kelompok kontrol berusia lebih tua dibanding kelompok perlakuan. Namun, uji statistik menunjukkan tidak terdapat perbedaan rerata usia $(p>0.05)$ yang bermakna antara kelompok perlakuan dan kontrol. Risiko menderita intoleransi glukosa meningkat seiring dengan meningkatnya usia. Prevalensi penderita diabetes di negara berkembang banyak ditemukan pada rentang usia 45-64 tahun. Hal ini terkait dengan terjadinya transisi ekonomi, sosial budaya dan epidemiologi. ${ }^{5}$ Di sisi lain, mulai terjadi penurunan fisiologis tubuh, aktifitas fisik dan massa otot yang menyebabkan terjadi banyak gangguan. Gangguan tersebut meliputi gangguan sekresi insulin, penurunan aktifitas insulin dalam menekan output glukosa hati dan resistensi insulin peripheral. ${ }^{19}$

Indeks Massa Tubuh (IMT) sebagian besar subjek tergolong Obesitas 1 dimana lebih banyak ditemukan pada kelompok kontrol (42.9\%) dibanding kelompok perlakuan (35.7\%). Uji statistik menunujukkan tidak terdapat perbedaan rerata IMT yang bermakna pada kedua kelompok $(p>0.05)$. Pada penderita obesitas berkembang resistensi terhadap aksi seluler insulin yang dikarakteristikkan oleh berkurangnya kemampuan insulin untuk menghambat pengeluaran glukosa dari hati dan kemampuannya untuk mendukung pengambilan glukosa pada lemak dan otot. Resistensi insulin disebabkan oleh sel-sel lemak yang mengalami hipertrofi menurunkan jumlah reseptor insulin. Jaringan lemak juga mensekresi beberapa protein dan hormon yang terkait dengan resistensi insulin seperti leptin, adiponektin, 
resistin, PAI-1, IL-6, TNF- $\alpha$ dan RBP4. Tingginya asam lemak, peningkatan hormon resistin dan penurunan adiponektin akibat penumpukan lemak pada penderita obesitas mempengaruhi kerja insulin sehingga dapat menyebabkan tingginya kadar glukosa darah. ${ }^{20}$

Subjek dengan aktifitas fisik sedang lebih banyak ditemukan pada kelompok kontrol $(42,9 \%)$ dibanding kelompok perlakuan $(39,3 \%)$. Uji statistik menunjukkan tidak terdapat perbedaan aktifitas fisik yang bermakna pada kedua kelompok $(p>0.05)$. Kurang aktifitas fisik merupakan salah satu penyebab kelebihan berat badan. Peningkatan aktifitas fisik dilakukan dengan berolahraga. ${ }^{2,18}$ Sebanyak $10,7 \%$ subjek penelitian masing-masing pada kelompok kontrol dan kelompok perlakuan memiliki kebiasaan olahraga dengan frekuensi 1-3 kali seminggu selama 30 menit. Olahraga memperbaiki metabolisme glukosa dan sensitifitas insulin, memberikan efek yang menguntungkan bagi metabolisme karbohidrat dan lemak, meningkatkan asupan glukosa oleh otot, serta berperan dalam penurunan berat badan., ${ }^{2,22}$ Jenis olahraga yang dilakukan subjek seperti bersepeda, jalan kaki dan senam. Seluruh subjek penelitian (100\%) merupakan ibu rumah tangga. Kesibukan di rumah menyebabkan sebagian besar subjek penelitian $(78,57 \%)$ tidak memiliki kebiasaan olahraga. Olahraga yang dianjurkan dilakukan teratur 3-5 kali per minggu, intensitas ringan dan sedang selama 30-60 menit. ${ }^{9}$

Rerata asupan energi dan lemak sebelum maupun selama intervensi kelompok kontrol lebih tinggi dari kelompok perlakuan. Uji independent $t$ test menunjukkan terdapat perbedaan rerata asupan energi dan lemak sebelum intervensi yang bermakna $(p<0.05)$ antara kelompok perlakuan dan kontrol. Namun, tidak terdapat perbedaan yang bermakna $(p>0.05)$ asupan energi dan lemak selama intervensi. Tingginya asupan energi disebabkan oleh tingginya asupan lemak yang berasal dari asupan makanan yang pengolahannya menggunakan minyak dan santan, seperti gorenggorengan serta sayur bersantan.

Rerata asupan karbohidrat kelompok kontrol lebih tinggi dari pada kelompok perlakuan, baik setelah intervensi maupun sebelum intervensi. Uji statistik menunjukkan tidak terdapat perbedaan asupan karbohidrat sebelum dan selama intervensi pada kedua kelompok $(p>0.05)$. Rerata asupan karbohidrat kelompok kontrol sebelum intervensi (243.15 \pm 32.31 gram) dan selama intervensi $(237,78 \pm 34.51$ gram $)$ mengalami penurunan. Hal ini karena subjek mengurangi porsi nasi tetapi tetap mengkonsumsi cemilan yang banyak mengandung karbohidrat sederhana; seperti roti manis, cake, gula pasir dan sirup. Sedangkan, pada kelompok perlakuan pemberian susu kedelai sebagai snack pagi memberikan rasa kenyang sehingga mengurangi asupan cemilan yang banyak mengandung karbohidrat sederhana. Subjek kelompok perlakuan lebih memilih mengkonsumsi cemilan seperti ubi dan singkong.

Penelitian menunjukkan bahwa makanan yang mengandung karbohidrat berbeda memiliki efek yang berbeda terhadap kadar glukosa darah. ${ }^{1}$ Karbohidrat kompleks diserap lebih lambat dibandingkan karbohidrat sederhana sehingga memperlambat peningkatan glukosa darah. Karbohidrat yang diserap lebih lambat dalam darah memiliki indeks glikemik (IG) yang rendah. Ubi jalar dan singkong memiliki IG yang tergolong rendah masing-masing 44 dan $46 .{ }^{23}$ Disamping itu, kedelai memiliki indeks glikemik yang rendah yaitu 31. Penelitian menunjukkan indeks glikemik yang rendah yang dimiliki kacang kedelai dan kacang merah dapat menurunkan glukosa darah pada tikus induksi aloksan. ${ }^{24}$ Adanya perbedaan jenis dan jumlah asupan karbohidrat pada kedua kelompok mempengaruhi penurunan kadar glukosa darah pada kelompok perlakuan dan peningkatan kadar glukosa darah pada kelompok kontrol atau sulitnya GDP kelompok kontrol untuk turun.

Intervensi dalam penelitian ini ialah pemberian $280 \mathrm{ml}$ susu kedelai/hari selama 14 hari. Persentase susu kedelai yang terasup 99,84\% yang diminum pada suhu ruang. Hal ini disebabkan sebanyak 1 orang subjek menyisakan $200 \mathrm{ml}$ susu kedelai selama 1 hari dengan alasan kekenyangan. Tingginya persentase susu kedelai yang terasup didukung oleh penambahan 1 sachet gula rendah kalori " $\mathrm{T}$ " (2 gram) yang mengandung pemanis sorbitol $1.97 \mathrm{mg}$, pemanis sukralose $9.8 \mathrm{mg}$ (Acceptable daily intake (ADI): $15 \mathrm{mg} / \mathrm{kg} \mathrm{BB} / \mathrm{hari}$, pemanis asesulfam $8 \mathrm{mg}$ (ADI: $15 \mathrm{mg} / \mathrm{kg} \mathrm{BB} / \mathrm{hari}$ ), bubuk jagung dan kromium pikolinat. Dosis pemberian gula tidak melebihi anjuran penggunaan yang aman dalam sehari. Penambahan gula rendah kalori ini bertujuan mengurangi asupan kalori dan meningkatkan cita rasa susu kedelai, sehingga dapat dihabiskan oleh subjek.

Pemberian susu kedelai selama 14 hari memberikan hasil penurunan kadar glukosa darah puasa yang bermakna $(p=0.001)$ pada kelompok perlakuan sebesar $26,31 \mathrm{mg} / \mathrm{dl}$, sedangkan pada kelompok kontrol terjadi peningkatan kadar glukosa darah puasa yang tidak bermakna 
( $p=0,916$ ) sebesar $0,07 \mathrm{mg} / \mathrm{dl}$. Uji beda perubahan GDP kedua kelompok menunjukkan terdapat perbedaan yang bermakna $(p=0.000)$ perubahan GDP antara kelompok perlakuan dan kelompok kontrol. Namun, penurunan GDP pada kelompok perlakuan tidak hanya dipengaruhi oleh asupan susu kedelai tetapi juga oleh aktifitas fisik, perubahan IMT dan perubahan asupan serat.

Hasil penelitian ini sejalan dengan hasil penelitian pemberian susu kedelai dalam diet pasien DM di Rumah Sakit dr. Saiful Anwar Malang dimana pengaturan diet dan pemberian susu kedelai menyebabkan penurunan yang bermakna glukosa darah puasa dan glukosa darah 2 jam post prandial. ${ }^{15}$ Pemberian 15 g protein kedelai dan $100 \mathrm{mg}$ isoflavon pada 180 wanita postmenopause Hongkong-Cina prediabetes menunjukkan hasil konsumsi protein kedelai dengan atau tanpa isoflavon tidak memperbaiki homeostasis glukosa darah dan sensitifitas insulin. ${ }^{7}$ Meskipun demikian, penelitian lain menunjukkan diet berbasis protein kedelai menguntungkan bagi kondisi yang berhubungan dengan gangguan intoleransi glukosa, hiperlipidemia, dan penurunan sensitifitas insulin. ${ }^{12}$

Protein kedelai dan isoflavon (genistein dan daidzein) dapat memperbaiki kondisi diabetes dengan menurunkan resistensi insulin dan simpanan lemak melalui beberapa mekanisme. Asupan asam amino arginin dan lisin terkait sekresi insulin dari pankreas. Pemberian asam amino arginin dan lisin saat terjadi peningkatan kadar glukosa darah, menyebabkan sekresi insulin yang diinduksi oleh glukosa meningkat 2 kali lipat sehingga memperkuat rangsangan glukosa terhadap sekresi insulin, kemudian insulin akan meningkatkan transpor glukosa ke dalam sel hati, otot, dan sel-sel lain sehingga kadar glukosa darah kembali normal. ${ }^{22}$ Isoflavon merupakan fitoestrogen dalam kedelai, memiliki struktur yang hampir sama dengan estrogen. Oleh karena itu, isoflavon dapat berperan sebagai estrogen yang berikatan dengan reseptor estrogen di sel beta pankreas. Adanya reseptor estrogen di sel beta pankreas akan menyebabkan pelepasan insulin. ${ }^{12}$ Genistein dan daidzein menghambat absorbsi glukosa ke dalam lumen usus halus sehingga menurunkan hiperglikemia. Genistein juga memiliki efek langsung terhadap metabolisme lemak di hati dan adiposa. Genistein menghambat sintesis lemak dari asetat dan glukosa tetapi menstimulasi lipolisis sehingga menurunkan simpanan lemak dan menurunkan resistensi insulin. $^{12}$
Uji laboratorium yang dilakukan di Laboratorium Universitas Soegijapranata menunjukkan aktifitas antioksidan susu kedelai yang diberikan dalam penelitian ini sebesar $4,722 \%$. Isoflavon yaitu genistein merupakan fitoestrogen dalam kedelai yang berperan sebagai antioksidan yang dapat menghambat oksidasi glukosa. ${ }^{12}$ Kandungan lesitin dalam kedelai juga berperan sebagai antioksidan yang mampu menjaga sel-sel pankreas agar tidak mengalami kerusakan akibat oksidasi. Lesitin juga mampu meregenerasi sel-sel yang rusak sehingga pankreas dapat berfungsi dengan baik kembali dan mampu memproduksi insulin secara optimal. ${ }^{15}$

Penurunan GDP pada kelompok perlakuan dipengaruhi oleh beberapa variable perancu. Hasil uji korelasi menunjukkan aktifitas fisik, perubahan IMT dan perubahan asupan serat berkorelasi positif secara bermakna $(p<0,05)$ dengan perubahan GDP. Semakin besar aktifitas fisik, perubahan IMT dan perubahan asupan serat semakin besar pula perubahan GDP. Aktifitas fisik ( $\mathrm{r}=0.769)$ maupun perubahan IMT $(\mathrm{r}=0.764)$ memiliki kekuatan korelasi yang kuat dengan perubahan GDP, sedangkan perubahan asupan serat $(\mathrm{r}=0.567)$ memiliki kekuatan korelasi yang sedang dengan perubahan GDP. Sebesar 56.10\% perubahan GDP dapat dijelaskan secara bersamaan oleh variabel aktifitas fisik, perubahan IMT dan perubahan asupan serat.

Asupan serat pada kelompok perlakuan meningkat pada akhir intervensi, sedangkan asupan serat pada kelompok kontrol menurun. Data food record menunjukkan peningkatan asupan serat disebabkan subjek meningkatkan asupan sayuran dan buah. Di samping itu, susu kedelai juga mengandung serat dalam jumlah kecil, meskipun demikian asupan ini dapat ikut berkontribusi dalam penurunan glukosa darah kelompok perlakuan.

Penelitian menunjukkan konsumsi makanan sangat tinggi serat dapat memperbaiki kontrol glukosa darah. ${ }^{1}$ Serat larut air dapat menunda dan mengurangi kenaikan kadar glukosa darah dengan meningkatkan waktu transit makanan di usus halus, menunda pengosongan lambung dan memperlambat absorbsi glukosa. ${ }^{19}$ Asupan serat selama intervensi antara kelompok perlakuan dan kontrol secara statistik tidak terdapat perbedaan yang bermakna $(p>0.05)$. Namun, jumlah asupan serat pada kelompok kontrol lebih rendah dibanding kelompok perlakuan. Rendahnya asupan serat pada kelompok kontrol memberi pengaruh sulitnya GDP kelompok kontrol untuk turun. 
Uji statistik menunjukkan tidak terdapat perbedaan yang bermakna rerata usia, IMT dan aktifitas fisik antara kelompok perlakuan dan kontrol. Meskipun demikian, kelompok kontrol tidak mengalami penurunan GDP dipengaruhi oleh rerata usia yang lebih tua, IMT yang lebih tinggi dan aktifitas fisik yang lebih rendah dibanding kelompok perlakuan. Penelitian ini telah membuktikan bahwa konsumsi susu kedelai memiliki pengaruh terhadap penurunan glukosa darah puasa pada dosis $280 \mathrm{ml} /$ hari; dimana aktifitas fisik, perubahan IMT dan perubahan asupan serat ikut berpengaruh terhadap penurunan kadar glukosa darah puasa.

\section{KETERBATASAN PENELITIAN}

Tidak dilakukan uji laboratorium untuk mengetahui besar kandungan protein, lemak, karbohidrat dan serat susu kedelai.

\section{SIMPULAN}

Terdapat penurunan kadar glukosa darah puasa yang bermakna sebesar $26,31 \mathrm{mg} / \mathrm{dl}$ setelah pemberian susu kedelai sebanyak $280 \mathrm{ml}$ selama 14 hari. Variabel aktifitas fisik, perubahan IMT dan perubahan asupan serat ikut berkontribusi $56.10 \%$ terhadap penurunan GDP.

\section{SARAN}

1. Diperlukan uji laboratorium untuk mengetahui besar kandungan protein, lemak, karbohidrat dan serat susu kedelai.

2. Penderita prediabetes dianjurkan untuk mengkonsumsi susu kedelai tawar dan meningkatkan asupan serat dan aktifitas fisik karena dapat membantu mengontrol kestabilan glukosa darah.

\section{DAFTAR PUSTAKA}

1. Whitney E, Rolfes SR, Pinna K. Nutrition and diabetes mellitus. Dalam : Understanding normal and clinical nutrition $7^{\text {th }}$ edition. Belmont : Wadsworth; 2002. Hal 790-816.

2. Villegas R, Gao YT, Gong Y, Li HL, Elasy TA, Zheng $\mathrm{W}$, et al. Legume and soy food intake and the incidence of type 2 diabetes in the Shanghai Women's Health Study. Am J Clin Nutr 2008;87:162-7.

3. Darmono. Pola hidup sehat penderita diabetes mellitus. Dalam : Naskah lengkap diabetes mellitus ditinjau dari berbagai aspek penyakit dalam, editor : Darmono, Suhartono T, Pemayun TGD, Padmomartono FS. Semarang : Badan Penerbit Universitas Diponegoro; 2007.
4. Wild S, Roglic G, Green A, Sicree R, King H. Global prevalence of diabetes: Estimates for the year 2000 and Projections for 2030. Diabetes Care 2004;27:1047-53

5. Soewondo P, Laurentinus AP. Prevalences, characteristics, and predictor of pre-diabetes in Indonesia. Jakarta : Department of Internal Medicine Faculty of Medicine University of Indonesia; 2011;20: 283-293.

6. Dinas Kesehatan Kota Semarang. Profil kesehatan Kota Semarang 2010. Semarang : Dinas Kesehatan Kota Semarang; 2010.

7. Liu ZM, Chen Y, Suzanne C Ho, Ho YP, Woo J. Effects of soy protein and isoflavones on glycemic control and insulin sensitivity: a 6-mo double-blind, Randomized, Placebo-Controlled Trial in Postmenopausal Chinese Women with Prediabetes or Untreated Early Diabetes. Am J Clin Nutr 2010;91:1394-40.

8. Perkumpulan Endokrinologi Indonesia. Konsensus pengelolaan dan pencegahan diabetes melitus tipe 2 di Indonesia. Jakarta : PB. PERKENI; 2006. Hal 3 14, 30-31.

9. Yunir EM, Soebardi S. Terapi non farmakologis pada diabetes melitus. Dalam : Buku ajar ilmu penyakit dalam jilid III edisi IV. Jakarta : Balai Penerbit Fakultas Kedokteran, Universitas Indonesia; 2006.

10. Villegas R, Gao YT, Yang G, Li HL, Elasy TA, Zheng $\mathrm{W}$, et al. Legume and soy food intake and incidence of type 2 diabetes in the Shanghai women's health study. Am J Clin Nutr 2008;87:162-7.

11. Marsono Y. Penentuan indeks glisemik kacangkacangan, factor determinan dan uji efek hipoglisemiknya [Tesis]. Yogyakarta: Universitas Gadja Mada; 2002.

12. Bhathena SJ, Velasquez MT. Beneficial role of dietary phytoestrogens in obesity and diabetes. Am J Clin Nutr. 2002;76:1191-1201.

13. Azadbakh L, Kimiagar M, Mehrabi Y, Esmaillzadeh A, Padyab M, Hu FB et al. Soy inclusion in the diet improves features of the metabolic syndrome: a randomized crossover study in postmenopausal women. Am J Clin Nutr 2007;85:735- 4 .

14. Khrisna R, Sudjatno HRM, Firmansah A. Perbandingan pemberian susu kedelai bubuk dan susu kedelai rumah tangga terhadap glukosa darah puasa pada tikus diabetes melitus hasil induksi aloksan monohidrat. MKB 2011;43(2):98-104.

15. Anitha C. Pengaruh pemberian susu kedelai terhadap kadar glukosa darah pada diet pasien diabetes mellitus di Rumah Sakit dr. Saiful Anwar Malang [Skripsi]. Malang: Universitas Brawijaya; 2006.

16. Harahap H, Widodo Y, Mulyati S. Penggunaan Berbagai Cut-Off Indeks Massa Tubuh sebagai Indikator Obesitas Terkait Penyakit Degeneratif di 
Indonesia. Pusat Penelitian dan Pengembangan Gizi dan Makanan, Badan Penelitian dan Pengembangan Kesehatan, Depkes; 2005.

17. Marsetyo H, Kartosaputra G. Ilmu Gizi (Korelasi Gizi, Kesehatan, dan Produktivitas Kerja). Jakarta : Rhineka Cipta; 2003. Hal 34-43.

18. Soegondo S, Soewondo P, Subekti I. Penatalaksanaan diabetes melitus terpadu. Jakarta : Pusat Diabetes dan Lipid RSUP Nasional Dr. Cipto Mangunkusumo Fakultas Kedokteran Universitas Indonesia; 2002.

19. Anderson JW. Diabetes mellitus : Medical nutriton therapy. Dalam : Shils ME, Shike M, Ross AC, Caballeru B, Cousins RJ. Modern nutrition in health and disease $210^{\text {th }}$ edition. USA : Lippincott Williams and Wilkins; 2006. Hal 1043-66.

20. Dewi, Mira. Resistensi insulin terkait obesitas: Mekanisme endokrin dan intrinsik sel. Jurnal Gizi dan Pangan, Juli 2007 2(2): 49-54.

21. Sizer FS, Whitney E. The Carbohydrates : Sugar, Strach, Glycogen and fibre. Dalam : Nutrition Concept and Controversies $11^{\text {th }}$ edition. Toronto: Wadsworth; 2008. Hal 121-138.

22. Guyton AC, Hall JE. Insulin, glukagon, dan diabetes melitus. Dalam : Buku ajar fisiologi kedokteran edisi 11. Jakarta : EGC; 2007. Hal 1010-28.

23. Rimbawan, Albiner S. Indeks glikemik pangan. Jakarta : Penebar Swadaya; 2004. Hal 23-70.

24. Sugano M. Soy in health and disease prevention. CRC : Taylor \& Francis; 2006. 